\title{
Current Status of Otolaryngological Diseases among Paediatric Population Attending ENT OPD in Sylhet Women Medical College
}

\author{
Dr. Md. Azadur Rahman ${ }^{1 *}$, Dr. Nasrin Jahan², Dr. Mst. Tamanna Begum ${ }^{3}$
}

${ }^{1}$ MBBS, DLO, Assistant Professor, Department of Otolaryngology-Head and Neck Surgery, Sylhet Women Medical College, Sylhet, Bangladesh

${ }^{2}$ MBBS, Outdoor Medical Officer, Department of Otolaryngology-Head and Neck Surgery, Sylhet Women Medical College, Sylhet, Bangladesh

${ }^{3}$ Medical Officer, TB Hospital, Sylhet, Bangladesh

DOI: $10.36347 /$ sjams.2020.v08i12.020

| Received: 20.03.2020 | Accepted: 28.03.2020 | Published: 16.12.2020

*Corresponding author: Dr. Md. Azadur Rahman

Abstract

Original Research Article

Objective: In this study our main goal is to evaluate current status of otolaryngological Diseases among Paediatric Population Attending ENT OPD in Sylhet women medical college. Methods: In this observational study, was conducted at Sylhet women medical college during January, 2018 to July 2019, where total number of 200 patients attended ENT OPD and among them 100 patients were children aged between 0-15 years presenting with ear, nose and throat diseases were taken as a study sample. Then parameter like: socio-demographic data such as age, residential area, types of ENT were collected from the patients parents using standard questionnaires and kept confidential during the research. Results: Most of the patients belong to in age group of 0-5 years and it was 55\%. During the study, otitis media with effusion (50\%) was the most common ear problem followed by wax (25\%). Also, rhinitis (35\%) was the commonest problem followed by sinusitis (29\%), epistaxis (20\%) and foreign body (10\%). Conclusion: According to the conducted study, otitis media, rhinitis and tonsillitis are most prevalent ENT disorder among paediatric study population presenting to ENT OPD during the study period. These acute problems if not diagnosed and managed accurately lead to chronic or recurring symptoms and ultimately either require surgical intervention or produce chronic morbidity.

Keywords: Otolaryngological Diseases, Paediatric Population, Otitis media.

Copyright $\odot 2020$ The Author(s): This is an open-access article distributed under the terms of the Creative Commons Attribution 4.0 International License (CC BY-NC 4.0) which permits unrestricted use, distribution, and reproduction in any medium for non-commercial use provided the original author and source are credited.

\section{INTRODUCTION}

Bangladesh forms the populous part of south Asia. The total population of this country is 163,654 , 860 (July 2013 estimated). Among the total population, $33 \%$ constitute the age group0-14 years (male 27,393,912; female26, 601, 199) [1]. Majority of admissions of paediatric population in different hospitals of the country are due to respiratory illness and acute watery diarrhea [2]. Morbidity pattern of this age group has several determining factors like socioeconomic status, basic education, occupation of parents, socio-cultural practices, living environment, etc[3].

Despite of vast improvement in health practices and various health facilities and awareness, various infections still remain one of the major causes of morbidity and mortality in paediatric age group.

Ear, nose and throat diseases (ENT) may adversely affect this ability and are common cause of consultation to medical practitioners. According to World Health Organization (WHO), 42 million people (age $>3$ yrs) of the world have hearing loss [4]. The majorcause of deafness being otitis media which is second to common cold as a cause of infection inchildren[5]. Common otolaryngological diseases in children include otitis media (acute and chronic), tonsillitis, acute laryngotracheobronchitis, adenoiditis, foreign body in ear-nose, and wax with or without fungal infection of ear, etc.

In this study our main goal is to evaluate current status of otolaryngological diseases among paediatric population attending ENT OPD in Sylhet women medical college.

\section{OBJECTIVE}

\section{General objective}

- To assess current status of otolaryngological Diseases among Paediatric Population Attending ENT OPD in Sylhet women medical college. 


\section{Specific objectives}

- To evaluate socioeconomic status of the patients.
- To detect percentage of nose diseases among study population.

\section{Methodology}

\begin{tabular}{|l|l|}
\hline Type of study & Observational study \\
\hline Place of study & Sylhet women medical college \\
\hline Study period & January, 2018 to July 2019 \\
\hline Study sample & $\begin{array}{l}\text { Total number of 200 patients attended ENT OPD and among them 100 patients was children aged } \\
\text { between 0-15 years presenting with ear, nose and throat diseases were taken as a study sample. }\end{array}$ \\
\hline $\begin{array}{l}\text { Sampling } \\
\text { technique }\end{array}$ & Purposive \\
\hline
\end{tabular}

\section{Exclusion Criteria}

Children with suspected neoplasm

\section{METHOD}

During the study, the study population was evaluated by history and complete ENT examination. Informed verbal consent was taken. Socio-demographic data such as age, residential area, types of ENT were collected from the patients' parents using standard questionnaires and kept confidential during the research.

\section{Data Analysis}

Statistical analysis was performed using the Statistical package for social science SPSS version 23.0. A descriptive analysis was performed for clinical features and results were presented as mean \pm standard deviation for quantitative variables and numbers (percentages) for qualitative variables

\section{RESULTS}

In table-1 shows distribution of age of the patients where most of the patients belong to in age group of 0-5 years and it was 55\%. The following table is given below in detail:

Table-1: Distribution of age of patients

\begin{tabular}{|l|c|}
\hline Age group & \% \\
\hline $0-5$ years & $55 \%$ \\
\hline $6-10$ years & $35 \%$ \\
\hline $11-15$ years & $10 \%$ \\
\hline
\end{tabular}

In figure-1 shows gender distribution the patients where overall ENT diseases were found more common in male children $(60 \%)$ than female children (40\%).The following figure is given below in detail:

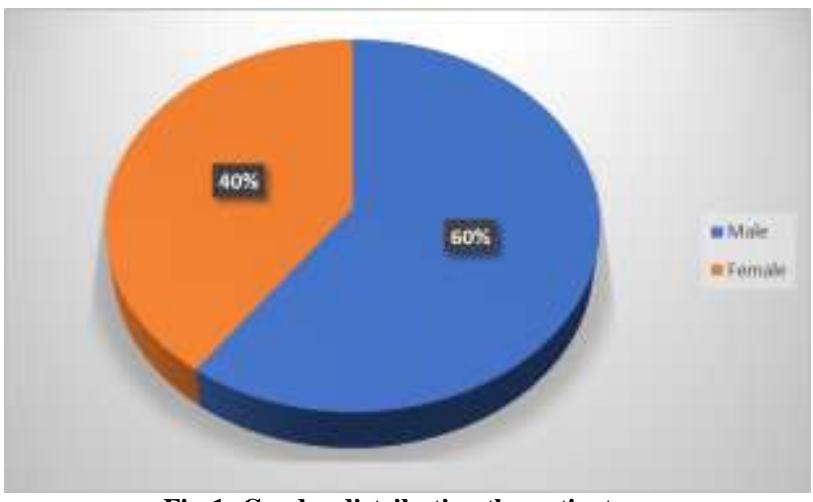

Fig-1: Gender distribution the patients.

In figure-2 shows socioeconomic status of the patients where majority $(52.32 \%)$ of the study population were from lower middle class, living in unhygienic environment with large family size and poor sanitation. The following figure is given below in detail:

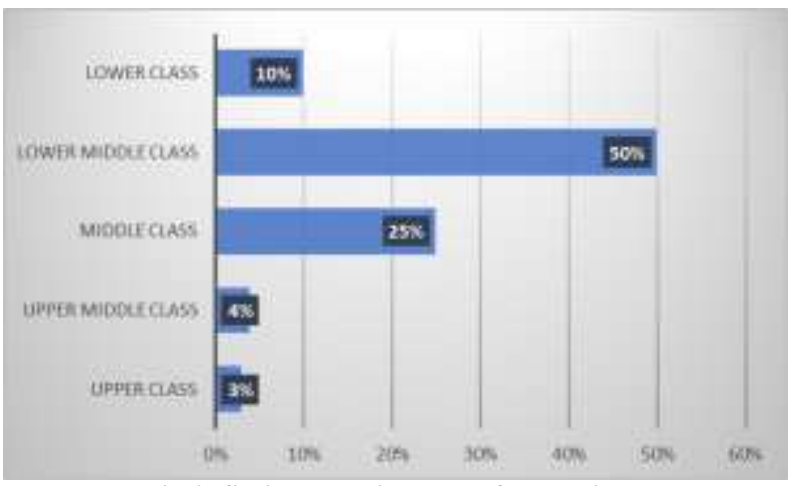

Fig-2: Socioeconomic status of the patients

In table- 2 shows residential area of the patients where most of the patients belong to rural area, $65 \%$. The following table is given below in detail:

Table-2: Residential area of the patients

\begin{tabular}{|l|l|}
\hline Residential area & $\mathbf{\%}$ \\
\hline Urban & $35 \%$ \\
\hline Rural & $65 \%$ \\
\hline
\end{tabular}


In table-3 shows distribution of ear diseases among study population where otitis media with effusion $(50 \%)$ was the most common ear problem followed by wax $(25 \%)$. The following table is given below in detail:

Table-3: Distribution of ear diseases

\begin{tabular}{|l|l|}
\hline Ear diseases & \% \\
\hline Otitis media with effusion & $50 \%$ \\
\hline Wax & $25 \%$ \\
\hline Foreign body & $15 \%$ \\
\hline Others & $10 \%$ \\
\hline
\end{tabular}

In table-4 shows percentage of nose diseases among study population where rhinitis (35\%) was thecommonest problem followed by sinusitis (29\%), epistaxis $(20 \%)$ and foreign body (10\%). The following table is given below in detail:

\section{Table-4: Percentage of nose diseases among study population

\begin{tabular}{|l|l|}
\hline Nose diseases & $\%$ \\
\hline Rhinitis & $35 \%$ \\
\hline sinusitis & $29 \%$ \\
\hline epistaxis & $20 \%$ \\
\hline foreign body & $10 \%$ \\
\hline Others & $6 \%$ \\
\hline
\end{tabular}

In figure-3 shows distribution of throat diseases ear diseases among study population where common throat problem found among our study population in decreasing order of percentage were tonsillitis (30\%), pharyngitis (25\%), enlarged adenoids $(21 \%)$, ALTB (15\%) and others (9\%). The following figure is given below in detail:

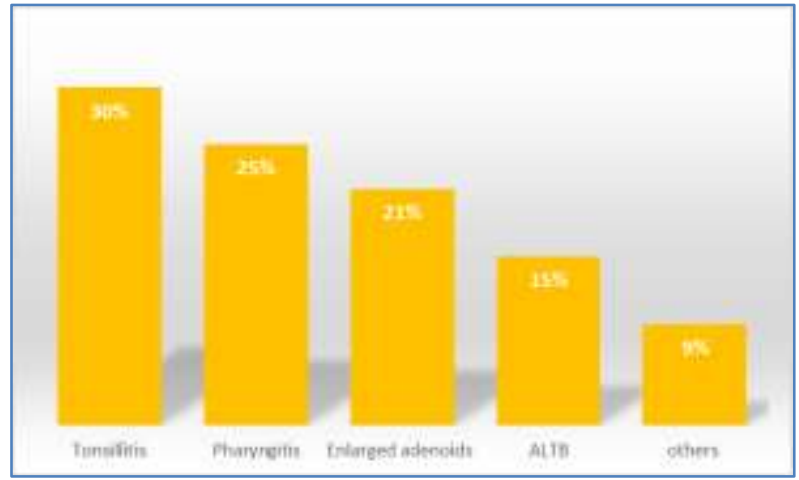

Fig-3: Distribution of throat diseases ear diseases among study population

\section{DisCUSSION}

In Bangladesh, common diseases of paediatric age group are malnutrition, ARI, diarrhoea, measles, malaria and other infectious diseases. ENT disorders may accompany these diseases or mayoccur independently. Though the government of Bangladesh has launched various health related programmes which work by early detection and appropriate intervention of common health problems among children, ENT diseases still remain one of the major causes of chronic morbidity due to lack of awareness among general population and parents[6].

In one study reported that, overall ENT diseases were found more common in male children $(52.79 \%)$ than female children $(47.20 \%)$ [7]. Which is quite similar to our study where most of the patients were male, $60 \%$ whereas female patients' percentage was $40 \%$.

In one study said that, otitis media (acute and chronic) and otitis media with effusion are the most common morbid conditions of the ear which if not treated accurately may lead to deafness. This high prevalence of otitis media inour study corresponds with that of other studies [8]. In our study we noted that, otitis media with effusion (50\%) was the most common ear problem followed by wax $(25 \%)$.

Young children particularly $<5$ years old have immature immune system and are prone to infection. Acute otitis media (AOM) is a common complication of upper respiratory tract infection whose pathogenesis involves both viruses and bacteria [9].

We also found that, rhinitis (35\%) was the commonest problem followed by sinusitis (29\%), epistaxis (20\%) and foreign body (10\%).In children; common presenting complaint of nose disorders is nasal obstructionand rhinorrhoea. These symptoms are commonly produced by rhinitis, allergy, naso pharyngitis and tonsillo adenoiditis [10].

Among throat infection acute and chronic tonsillitis is the commonest throat problem usually occurring in children aged 3-15 years.13 In our study we found, tonsillitis (30\%), pharyngitis $(25 \%)$, enlarged adenoids (21\%), ALTB (15\%) and others (9\%).

\section{Conclusion}

From our study we can conclude that, otitis media, rhinitis and tonsillitis are most prevalent ENT disorder among paediatric study population presenting to ENT OPD during the study period. These acute problems if not diagnosed and managed accurately lead to chronic or recurring symptoms and ultimately either require surgical intervention or produce chronic morbidity.

\section{REFERENCES}

1. Index Mundi [Internet]. Bangladesh Demographic Profile. 2013 (cited 2014 march 22). Available from: http://www.indexmundi.com/bangladesh/.

2. Hasan MS, Barua ST, Mahmud MN, Kamal AHM,Enayetullah M, Karim MR. Disease Profile and Death Pattern among Children Admitted in a 
Medical College Hospital. Bangladesh J Child Health. 2012;36(2):66-67.

3. Roy E, Hasan KZ, Richards JL, Haque AKMF,Siddique AK, Sack RB. Burden and Outcome ofAcute Otitis Media in Rural Bangladesh. S a Journal of child health. 2012; 6(4):118-22.

4. Morris PS, Leach AJ. Acute and Chronic OtitisMedia. Paediatric Clin North America.2009;56(6):1383-99.

5. Kishve SP, Kumar N, Kishve PS, Arif SMM,Kalakoti P. Ear, Nose and Throat Disorders in Paediatric Patients at a Rural Hospital in India. AMJ.2010;3(12):786-90.

6. Shaheen MM, Raquib A, Ahmad SM. ChronicSuppurative Otitis Media and Its Association with Socieo Economic Factors among Rural PrimarySchool Children of Bangladesh.
Indian JOtolaryngology Head Neck Surgery.2012;64(1):36-41.

7. Sophia A, Isaac R, Rebekah G, Brahmadath K, RupaV. Risk Factors for Otitis Media among Preschool Rural Indian Children. Int J Paediatric Otolaryngology. 2010;74(6):677-83.

8. Kliegman RM, Jenson HB, Behrman RE, StantonBF, editors. Nelson Textbook of Pediatrics. 18th ed. Philadelphia (PA): Elsevier; 2007: 179599.

9. Pettigrew MM, Gent JF, Pyles RB, Miller AL,Nokso-Koivisto J, Chonmaitree T. ViralBacterialInteractions and Risk of Acute Otitis MediaComplicating Upper Respiratory Tract Infection. J Clin Microbiol. 2011;49(11):3750-55.

10. Ahn YM. Treatment of Obstructive Sleep Apnea in Children. Korean J Pediatr. 2010;53(10):872-79. 